Article

\title{
Virulence of Two Entomophthoralean Fungi, Pandora neoaphidis and Entomophthora planchoniana, to Their Conspecific (Sitobion avenae) and Heterospecific (Rhopalosiphum padi) Aphid Hosts
}

\author{
Ibtissem Ben Fekih ${ }^{1,2,3, * \mathbb{D}}$, Annette Bruun Jensen ${ }^{2}$, Sonia Boukhris-Bouhachem ${ }^{1}$, \\ Gabor Pozsgai ${ }^{4,5, *(\mathbb{C})}$, Salah Rezgui ${ }^{6}$, Christopher Rensing ${ }^{3}(\mathbb{C})$ and Jørgen Eilenberg ${ }^{2}$ \\ 1 Plant Protection Laboratory, National Institute of Agricultural Research of Tunisia, Rue Hédi Karray, \\ 2049 Ariana, Tunisia; soribou@yahoo.fr \\ 2 Department of Plant and Environmental Sciences, Faculty of Science, University of Copenhagen, \\ Thorvaldsensvej 40, 3rd floor, 1871 Frederiksberg C, Denmark; abj@plen.ku.dk (A.B.J.); jei@plen.ku.dk (J.E.) \\ 3 Institute of Environmental Microbiology, College of Resources and Environment, Fujian Agriculture and \\ Forestry University, Fuzhou 350002, China; rensing@fafu.edu.cn \\ 4 State Key Laboratory of Ecological Pest Control for Fujian and Taiwan Crops, Fujian Agriculture and \\ Forestry University, Fuzhou 350002, China \\ 5 Institute of Applied Ecology, Fujian Agriculture and Forestry University, Fuzhou 350002, China \\ 6 Department of ABV, National Agronomic Institute of Tunisia, 43 Avenue Charles Nicolle, 1082 EL Menzah, \\ Tunisia; salahrezgui@yahoo.fr \\ * Correspondence: fekih.ibtissem@gmail.com (I.B.F.); pozsgaig@coleoptera.hu (G.P.)
}

Received: 3 December 2018; Accepted: 2 February 2019; Published: 13 February 2019

\begin{abstract}
Pandora neoaphidis and Entomophthora planchoniana (phylum Entomophthoromycota) are important fungal pathogens on cereal aphids, Sitobion avenae and Rhopalosiphum padi. Here, we evaluated and compared for the first time the virulence of these two fungi, both produced in S. avenae cadavers, against the two aphid species subjected to the same exposure. Two laboratory bioassays were carried out using a method imitating entomophthoralean transmission in the field. Healthy colonies of the two aphid species were exposed to the same conidial shower of P. neoaphidis or E. planchoniana, in both cases from a cadaver of $S$. avenae. The experiments were performed under LD 18:6 $\mathrm{h}$ at $21^{\circ} \mathrm{C}$ and a successful transmission was monitored for a period of nine days after initial exposure. Susceptibility of both S. avenae and R. padi to fungal infection showed a sigmoid trend. The fitted nonlinear model showed that the conspecific host, S. avenae, was more susceptible to E. planchoniana infection than the heterospecific host R. padi, was. In the case of P. neoaphidis, $\mathrm{LT}_{50}$ for $S$. avenae was 5.0 days compared to 5.9 days for R. padi. For E. planchoniana, the $\mathrm{LT}_{50}$ for $S$. avenae was 4.9 days, while the measured infection level in R. padi was always below 50 percent. Our results suggest that transmission from conspecific aphid host to heterospecific aphid host can occur in the field, but with expected highest transmission success to the conspecific host.
\end{abstract}

Keywords: aphids; Pandora neoaphidis; Entomophthora planchoniana; virulence

\section{Introduction}

Sitobion avenae (Fabricius, 1775) and Rhopalosiphum padi (Linnaeus, 1758) aphids are serious pests, commonly coexisting in cereal fields [1-3]. Both species can cause economic damage through their feeding activity and their role in the dissemination of phytoviruses, such as the Barley Yellow Dwarf Virus (BYDV) [3]. Entomophthoralean fungi such as Pandora neoaphidis (Remaudière et Hennebert) and Entomophthora planchoniana Cornu are obligate aphid pathogens [4-7] and can cause epizootics 
among aphids in cereals [4,8-11]. It is however not known to which extent infection can be transmitted between $S$. avenae and $R$. padi in the field and if an epizootic in one of these aphid species can result in infection in the other aphid species.

To understand the transmission of a fungal pathogen between aphid host species occurring in the same crop, we need comparative virulence bioassay studies mimicking the situation occurring in the field. Virulence studies with hypocrealean insect pathogenic fungi, such as species from the genera Beauveria and Metarhizium, can be done by subjecting the target insect to suspensions with a predefined, known concentration of conidia. This is possible because these hypocrealean fungi have small, dry conidia which can readily be dissolved in water supplemented with a detergent $[12,13]$. Entomophthoralean fungi, however, have large, sticky conidia which are actively discharged from dead insects before landing on the cuticle of an uninfected individual [14-17]. These conidia cannot be dissolved in water due to their sticky nature, so assays with predefined concentrations are technically not feasible.

The main methods for performing bioassays of entomophthoralean fungi have therefore to focus on alternatives. Insects are placed in small plastic cups and subjected to conidia discharged from insect cadavers or from mycelial mats produced in vitro [13,18-22]. Measuring the conidia concentrations can, to some extent, be done by adding cover slips in the cups during exposure and afterwards counting conidia on these cover slips [13,22,23]. Such methods have the general drawback that conidia concentrations cannot be precisely predefined, so exposing replicates to the exact same conidia concentrations is almost impossible to achieve. A main challenge in comparative studies on the virulence of entomophthoralean fungi to different hosts is therefore to apply a method that allows comparisons between replicates. Besides, of course, sample size and replicates should be sufficient to allow comparisons.

Our aim was to tackle this issue and to study the virulence of the two entomophthoralean fungi P. neoaphidis and E. planchoniana (both produced in S. avenae) against the two aphid species S. avenae and $R$. padi when exposed to the same conidial exposure. Our hypothesis was that the virulence against conspecific and heterospecific hosts differs, and we predicted a higher virulence against the conspecific host.

\section{Materials and Methods}

\subsection{Rearing of Target Aphids}

S. avenae and R. padi were originally provided on barley banker plants from EWH BioProduction ApS (Tappernøje, Denmark). Colonies of both aphid species were transferred to wheat plant and maintained separately in ventilated plexiglass cages $(0.60 \mathrm{~m} \times 0.30 \mathrm{~m} \times 0.30 \mathrm{~m})$ at $21^{\circ} \mathrm{C}$. Boxes with fresh wheat plants (cultivar Dacanto) were provided weekly to maintain the rearing of target aphids.

\subsection{Sampling and Inoculum Preparation}

Barley leaves and inflorescences infested with S. avenae were sampled at Bakkegaarden, an experimental agricultural field in Taastrup belonging to University of Copenhagen. Samples were kept in ventilated boxes and brought to the laboratory for microscope examination. Living apterous adults of $S$. avenae were picked up and incubated individually in small sterilized plastic cups (30 mL) containing $1.5 \%$ water-agar. Pieces of wheat leaves secured in the water-agar served as a food source for the aphids and the cups were maintained in an incubator at $21{ }^{\circ} \mathrm{C}$ under LD 18:6. Aphids were checked daily for cases of entomophthoralean infection. The investigation of new cases of mycosis was performed for 7 days, the time required for the development of fungus in the suspected infected aphids. Once dead, S. avenae cadavers, both with or without external signs of fungal structures, were carefully picked up from the wheat leaves and placed for incubation in a humid chamber on the top of a $15 \mathrm{~mm} \times 15 \mathrm{~mm}$ cover slip for $12-24 \mathrm{~h}$ at $21^{\circ} \mathrm{C}$ to promote conidiophores development and thus conidia discharge. The first projected conidia from each cadaver were mounted in lactic acid and 
used for identification of fungus species using phase-interference on an Olympus AX70 Provis light microscope at $400 \times$ magnification and related keys [24]. Sterile fine forceps were used during the manipulation to avoid cross contamination. Only S. avenae cadavers with good sporulation of either P. neoaphidis or E. planchoniana were used in the bioassay.

\subsection{Bioassay Setup}

For the transmission, we established an environment mimicking field situations by introducing both aphid species in the same inoculation cups with small wheat leaves as food source. The bioassay procedure was based on descriptions of entomophthoralean bioassays [22]. Ten apterous young adults of $S$. avenae and ten R. padi were transferred jointly onto fresh wheat leaves in each cup. The two main reasons for doing so are these: First, that by being together, the two aphid species in each cup were allowed to place themselves on the leaves according to their habitat preferences, and second, afterward they were subjected to the same conidial shower as in real field conditions. A freshly sporulating cadaver of $S$. avenae was attached with Vaseline ${ }^{\circledR}$ onto the inner side of a lid and placed over the ten S. avenae and ten R. padi (Figure 1). Controls included the same number of aphids just without the sporulating aphid cadaver. Five replications, each using new cadavers, were performed for each of the two fungus treatments (E. planchoniana and P. neoaphidis, respectively). Healthy aphids were exposed to conidial showers for six hours in a humid chamber. Then, the inoculum was removed, and the cups were incubated at $21^{\circ} \mathrm{C}$ under LD 18:6 h. Twenty-four hours from the exposure, treated aphids were transferred into individual cups to avoid cross-infection between aphid specimens. Fresh wheat leaves were provided for each aphid and incubation was conducted under the same conditions as above. Incubated aphids were inspected daily for mycosis for eight days after exposure. Each day, dead aphids were collected and checked for the presence of fungal structures (conidia, conidiophores or rhizoids) using a dissecting light microscope and were later incubated in a humid chamber for $12-24 \mathrm{~h}$ at $21^{\circ} \mathrm{C}$. After incubation, aphid cadavers with no external signs of infection were dissected and stained with lactic acid to look for the presence of resting spores. In total, 50 S. avenae and 50 R. padi were exposed to fungal treatments. During the study, dead aphids with no observed signs of fungal infection were also recorded.

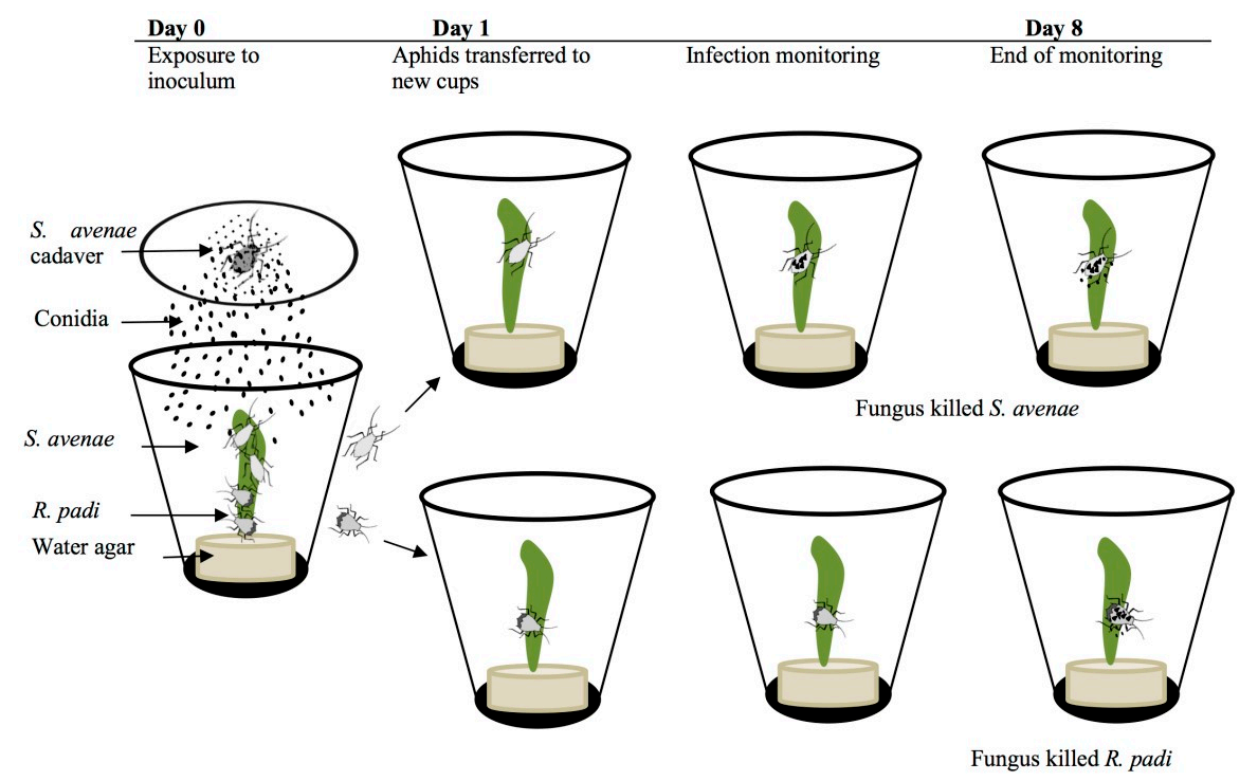

Figure 1. Inoculation and monitoring procedure of the aphids Sitobion avenae and Rhopalosiphum padi exposed to the fungi Pandora neoaphidis or Entomophthora planchoniana using the conidia shower method. Ten specimens of each of the two aphid species were infected in the same cup simultaneously to ensure they were exposed to same conidia concentration. 


\subsection{Data Analysis}

Overall mortalities, with or without observed sign of fungal infection, were counted and arcsine transformed, following the formula [Arcsin $((\sqrt{ } \times) / 100)]$ to standardize the data distribution and stabilize the variance [25]. Repeated measures ANOVA was used to test whether mortalities after fungal treatments were different from those registered within control.

Afterward, only aphids showing clear fungal structures were considered as mortality counts in the analysis. Cumulative mortality percentages for each day of incubation were also arcsine transformed. A non-linear least-square regression model was fitted on the time-mortality data of the aphids from each fungus infection (M), using the nls () function in R statistical software [26] with the implemented Gauss-Newton algorithm. Packages "data.frame" [27] and "investr" [28] were used to facilitate the analysis. The adopted model is expressed as $M(i j)=k /(1+\exp (a+b \times T))$ where $M$ is the cumulative mortality, $i$ and $j$ referring to aphid and fungus species, respectively, parameter $\mathrm{k}$ is a maximal that $\mathrm{M}$ could reach during the bioassay, $b$ is the intercept for the generated curve, and c the evolution rate of M (ij) over time (T). Since R-square values for non-linear models cannot be calculated directly, Efron's pseudo R-squares were used [29]. One-way ANOVA coupled with a post-hoc Tukey test [30] were used to test for significant differences between the final maximum mortality for each treatment and to examine whether the non-linear least-square regression curves were significantly different. Median lethal time $\left(\mathrm{LT}_{50}\right)$ for each tested aphid and fungus species combination was estimated using the invest () function from the "investor" R package [28]. T-tests were performed to compare the $\mathrm{LT}_{50}$ values.

\section{Results}

The mortality in the untreated controls was $13.3 \%( \pm 5.8)$ for $S$. avenae and $16.7 \%( \pm 5.8)$ for $R$. padi after nine days. The non-fungal mortality rate of $P$. neoaphidis exposed aphids (uncertain cause of death with no fungal symptom) was $12.0 \%( \pm 8.4)$ for $S$. avenae and $14.0 \%( \pm 5.5)$ for $R$. padi and non-fungal mortality of the E. planchoniana exposed aphids was $12.0 \%( \pm 8.4)$ for $S$. avenae and $26.0 \%( \pm 5.5)$ for $R$. padi (Supplementary Materials). We find significant differences in the overall mortalities over time between the different treatments (control, P. neoaphidis and E. planchoniana) $(p<0.0001)$ and aphid species $(p<0.0001)$ (Table 1$)$.

Table 1. Results of ANOVA analysis comparing the overall mortalities over time for each aphid species for the adopted treatments. The interactions between aphid species, treatments and aphid species were also analyzed. Abbreviations: $d f=$ degree of freedom, $S u m S q=$ sum of squares, $M e a n S q=$ mean of squares, $F=$ test value, $p=$ significance level. Values in bold indicate significant differences $(p \leq 0.05)$.

\begin{tabular}{cccccc}
\hline & \multicolumn{5}{c}{ ANOVA } \\
\cline { 2 - 6 } & SumSq & Df & MeanSq & $\boldsymbol{F}$ & $\boldsymbol{p}$ \\
\hline Time (T) & 14.239 & 1 & 14.239 & 1388.45 & $<\mathbf{0 . 0 0 0 1}$ \\
Treatments (R) & 14.295 & 2 & 7.148 & 696.98 & $<\mathbf{0 . 0 0 0 1}$ \\
Aphid species (A) & 0.661 & 1 & 0.661 & 64.452 & $<\mathbf{0 . 0 0 0 1}$ \\
$\mathrm{T}^{*} \mathrm{R}$ & 8.688 & 2 & 4.344 & 423.575 & $<\mathbf{0 . 0 0 0 1}$ \\
$\mathrm{T}^{*} \mathrm{~A}$ & 0.117 & 1 & 0.117 & 11.441 & $\mathbf{0 . 0 0 0 8}$ \\
$\mathrm{R}^{*} \mathrm{~A}$ & 0.463 & 2 & 0.232 & 22.59 & $<\mathbf{0 . 0 0 0 1}$ \\
$\mathrm{T}^{*} \mathrm{R}^{*} \mathrm{~A}$ & 0.071 & 2 & 0.035 & 3.451 & 0.0332 \\
Residuals & 2.502 & 244 & 0.010 & & \\
\hline
\end{tabular}

The total numbers of fungus infections in the treated groups were as follows: after exposure to P. neoaphidis $80.0 \%( \pm 7.1)$ of exposed $S$. avenae and $66.0( \pm 5.5) \%$ of $R$. padi got infected; after exposure to E. planchoniana $68.0 \%( \pm 8.4)$ of $S$. avenae and $48.0 \%( \pm 11.0)$ of $R$. padi got infected. Significant differences were detected between the total numbers of fungus infections for each aphid species after treatments (Table 2). 
Table 2. Results of ANOVA analysis comparing the total numbers of fungus infections values for each aphid species after infection by P. neoaphidis and E. planchoniana. The interaction between aphid species and fungus species was also analyzed. Abbreviations: $d f=$ degree of freedom, $S u m S q=$ sum of squares, MeanS $q=$ mean of squares, $F=$ test value, $p=$ significance level. Values in bold indicate significant differences $(p \leq 0.05)$.

\begin{tabular}{llllll}
\hline & \multicolumn{5}{c}{ ANOVA } \\
\cline { 2 - 6 } & SumSq & $d f$ & MeanSq & $\boldsymbol{F}$ & $\boldsymbol{p}$ \\
\hline Fungus species (F) & 0.131 & 1 & 0.131 & 16.13 & $\mathbf{0 . 0 0 0 1}$ \\
Aphid species (A) & 0.172 & 1 & 0.172 & 21.07 & $\mathbf{0 . 0 0 0 3}$ \\
F $^{*}$ A & 0.002 & 1 & 0.002 & 0.30 & 0.587 \\
Residuals & 0.130 & 16 & 0.008 & & \\
\hline
\end{tabular}

Even though the ANOVA did not result in detection of an effect of the interaction between the two variables (fungi and aphid species), the post-hoc test detected significant differences between three specific combinations (Table 3). The total number of $R$. padi cadavers infected with E. planchoniana was significantly lower than that of $S$. avenae infected with the same fungus $(p=0.0107)$.

Table 3. Results of Post-hoc Tukey test for multiple comparisons of means with $95 \%$ family-wise confidence level. Abbreviations: diff = difference between group means, lower = lower end point of the interval, upper = upper end point of the interval, $p=$ significance level. Values in bold indicate significant differences $(p \leq 0.05)$ between the different combinations of the treatment and aphid host species.

\begin{tabular}{cccccc}
\hline & & \multicolumn{4}{c}{ Post-hoc Tukey Test } \\
\cline { 3 - 6 } Combination 1 & Combination 2 & Diff & Lower & Upper & $p$ \\
\hline P. neoaphidis-R. padi & E. planchoniana-R. padi & 0.184 & 0.021 & 0.348 & $\mathbf{0 . 0 1 0 0}$ \\
E. planchoniana-S. avenae & E. planchoniana-R. padi & 0.207 & 0.044 & 0.371 & $\mathbf{0 . 0 1 0 7}$ \\
P. neoaphidis-S. avenae & E. planchioniana-R. padi & 0.347 & 0.184 & 0.511 & $<\mathbf{0 . 0 0 0 1}$ \\
E. planchoniana-S. avenae & P. neoaphidis-R. padi & 0.023 & -0.140 & 0.186 & 0.9766 \\
P. neoaphidis-S. avenae & P. neoaphidis-R. padi & 0.163 & -0.0003 & 0.326 & 0.0506 \\
P. neoaphidis-S. avenae & E. planchoniana-S. avenae & 0.140 & -0.023 & 0.303 & 0.1074 \\
\hline
\end{tabular}

The time-mortality data $M(i j)$ fitted well to the adopted non-linear estimation (Table 4) for S. avenae infected with $P$. neoaphidis $\left(\mathrm{R}^{2}=0.96\right)$ or E. planchoniana $\left(\mathrm{R}^{2}=0.96\right)$ and fitted also for $R$. padi infected with P. neoaphidis $\left(\mathrm{R}^{2}=0.97\right)$ or E. planchoniana $\left(\mathrm{R}^{2}=0.93\right)$.

Table 4. Estimation of the non-linear least-square regression model of the mortality of Sitobion avenae and Rhopalosiphum padi to fungal infection.

\begin{tabular}{|c|c|c|c|c|c|c|c|c|}
\hline \multirow{2}{*}{$\begin{array}{l}\text { Fungus } \\
\text { Species }\end{array}$} & \multirow{2}{*}{$\begin{array}{l}\text { Aphid } \\
\text { Species }\end{array}$} & \multicolumn{7}{|c|}{ Estimated Parameters ${ }^{a}$ and Fitness } \\
\hline & & K (SD) & $t$-Values & a (SD) & $t$-Values & b (SD) & $t$-Values & $R^{2}$ \\
\hline P. neoaphidis & S. avenae & $1.124( \pm 0.036)$ & 31.42 & $5.497( \pm 0.591)$ & 9.30 & $-0.053( \pm 0.006)$ & -8.66 & 0.96 \\
\hline \multirow{2}{*}{ E. planchoniana } & S. avenae & $0.983( \pm 0.026)$ & 37.31 & $5.596( \pm 0.63)$ & 8.88 & $-0.06( \pm 0.007)$ & -8.51 & 0.96 \\
\hline & R. padi & $0.77( \pm 0.034)$ & 22.66 & $7.714( \pm 1.332)$ & 5.79 & $-0.067( \pm 0.012)$ & -5.56 & 0.93 \\
\hline
\end{tabular}

The proportion of mortality over time followed a sigmoid shape for the different treatments (Figure 2). 


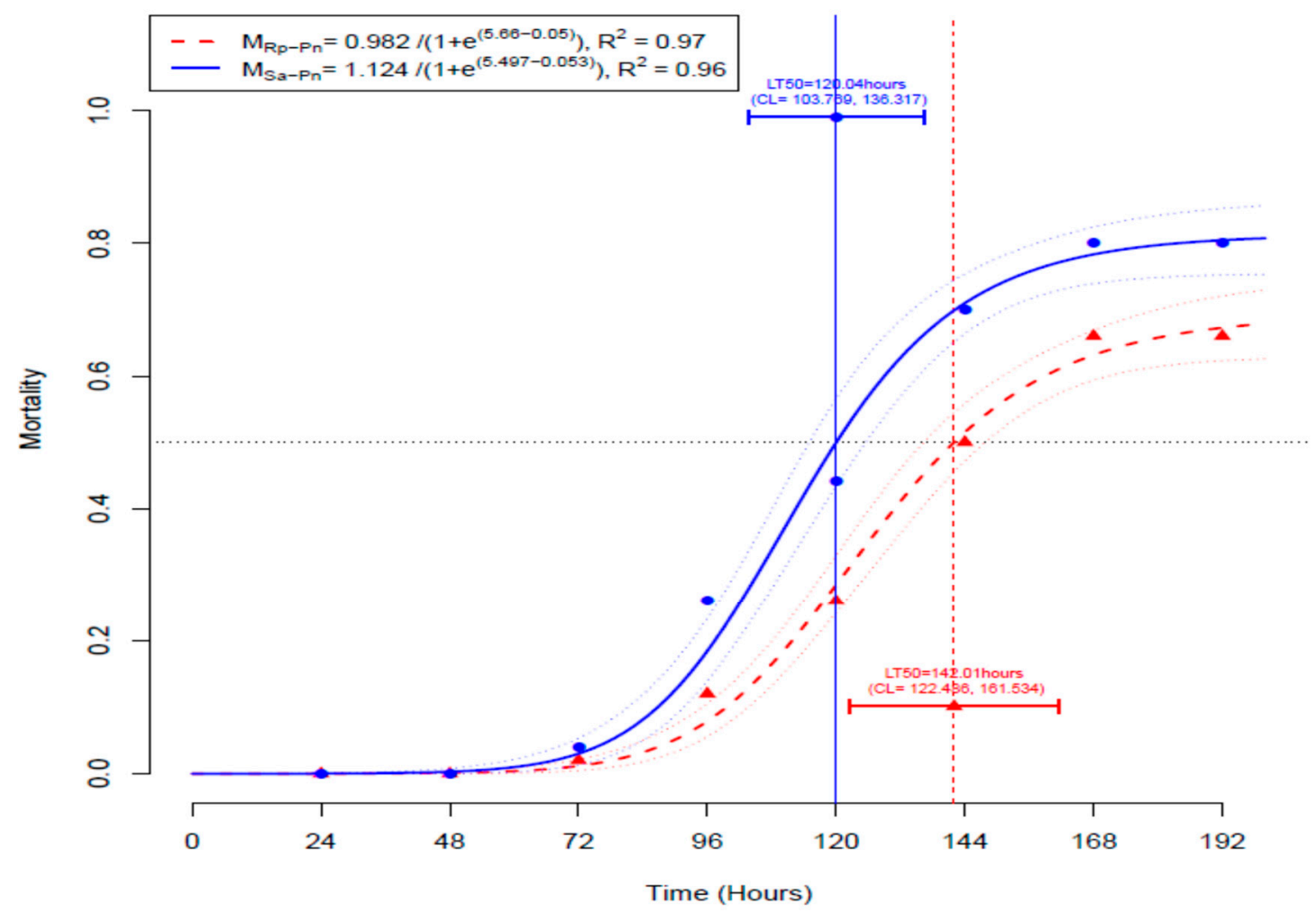

(a)

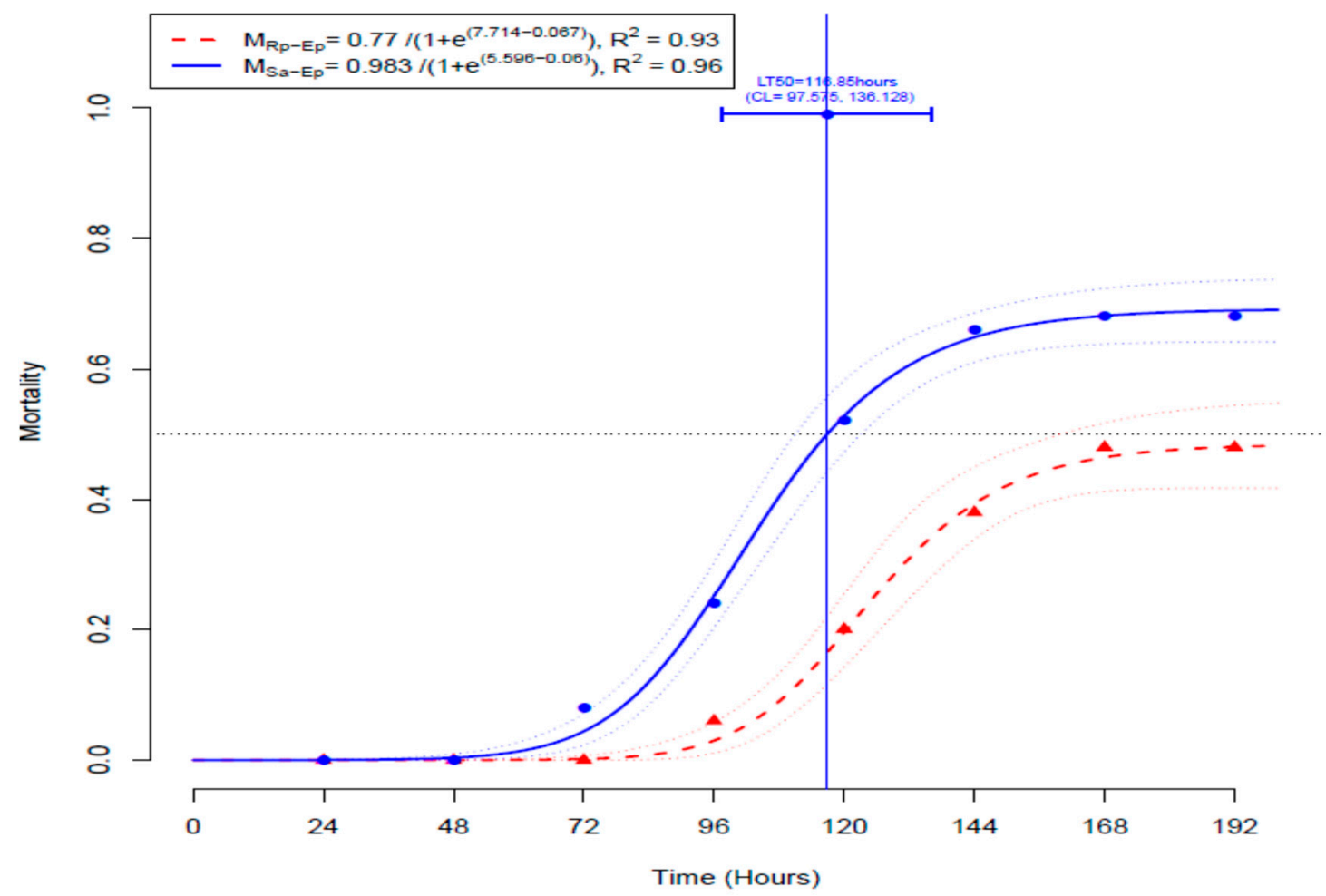

(b)

Figure 2. Time-mortality of fungus infected aphids. (a) Sitobion avenae $\left(\mathrm{M}_{\mathrm{Sa}-\mathrm{Pn}}\right)$ and Rhopalosiphum padi $\left(\mathrm{M}_{\mathrm{Rp}-\mathrm{Pn}}\right)$ infected with Pandora neoaphidis. (b) Sitobion avenae $\left(\mathrm{M}_{\mathrm{Sa}-\mathrm{Ep}}\right)$ and Rhopalosiphum padi $\left(\mathrm{M}_{\mathrm{Rp}-\mathrm{Ep}}\right)$ infected with Entomophthora planchoniana. 
Significant differences between the non-linear regression models were detected (Table 5), reflecting the differences between the aphid mortality from fungal treatments. In fact, the post-hoc Tukey test (Table 6) showed a significantly lower mortality rate of $R$. padi by E. planchoniana infection compared to the one registered for $S$. avenae either infected with E. planchoniana $(p=0.0032)$ or with $P$. neoaphidis $(p=0.0010)$. No significant difference was found between the mortality of $S$. avenae and $R$. padi over time after infection with $P$. neoaphidis.

Table 5. Results of ANOVA analysis comparing the designed non-linear least-square regression models for each treatment. Abbreviations: $d f=$ degree of freedom, $S u m S q=$ sum of squares, MeanS $q=$ mean of squares, $F=$ test value, $p=$ significance level. Values in bold indicate significant interactions $(p \leq 0.05)$.

\begin{tabular}{llllll}
\hline & \multicolumn{5}{c}{ ANOVA } \\
\cline { 2 - 6 } & SumSq & $d f$ & MeanSq & $F$ & $p$ \\
\hline Models & 2.81 & 3 & 0.935 & 6.15 & $\mathbf{0 . 0 0 0 4}$ \\
Residuals & 60.25 & 396 & 0.152 & & \\
\hline
\end{tabular}

Table 6. Results of post-hoc Tukey test for multiple comparisons of means with $95 \%$ family-wise confidence level. Abbreviations: diff = difference between group means, lower = lower end point of the interval, upper $=$ upper end point of the interval, $p=$ significance level. Values in bold indicate significant differences $(p \leq 0.05)$ between the different non-linear regression models.

\begin{tabular}{cccccc}
\hline & & \multicolumn{3}{c}{ Post-hoc Tukey Test } \\
\cline { 3 - 5 } Model 1 & Model 2 & Diff & Lower & Upper & p \\
\hline P. neoaphidis-R. padi & E. planchoniana-R. padi & 0.093 & -0.049 & 0.235 & 0.3318 \\
E. planchoniana-S. avenae & E. planchoniana-R. padi & 0.191 & 0.048 & 0.333 & $\mathbf{0 . 0 0 3 2}$ \\
P. neoaphidis-S. avenae & E. planchioniana-R. padi & 0.208 & 0.066 & 0.351 & $\mathbf{0 . 0 0 1 0}$ \\
E. planchoniana-S. avenae & P. neoaphidis-R. padi & -0.098 & -0.240 & 0.044 & 0.2839 \\
P. neoaphidis-S. avenae & P. neoaphidis-R. padi & 0.115 & -0.026 & 0.258 & 0.1547 \\
P. neoaphidis-S. avenae & E. planchoniana-S. avenae & 0.017 & -0.124 & 0.159 & 0.9887 \\
\hline
\end{tabular}

$\mathrm{LT}_{50}$ estimates of $S$. avenae and $R$. padi infected with $P$. neoaphidis were 5.0 days $(\mathrm{CL}=4.3,5.7)$ and 5.9 days $(\mathrm{CL}=5.1,6.7)$, respectively. The estimated $\mathrm{LT}_{50}$ of $S$. avenae after E. planchoniana treatment was 4.9 days $(\mathrm{CL}=4.1,5.7)$. However, it was not possible to estimate $\mathrm{LT}_{50}$ for $R$. padi since the maximum mortality reached only $48.0 \%( \pm 11.0)$ after the E. planchoniana treatment. The $t$-tests comparing the measured $\mathrm{LT}_{50}$ showed no significant differences between the values (Table 7).

Table 7. Results of $\mathrm{t}$-tests for $\mathrm{LT}_{50}$ comparisons. Abbreviations: ne = non estimated values due to the absence of $\mathrm{LT}_{50}$ related to the mortality of $R$. padi after treatment with E. planchoniana.

\begin{tabular}{ccc}
\hline Model 1 & Model 2 & t-Values \\
\hline E. planchoniana-R. padi & E. planchoniana-S. avenae & ne \\
E. planchoniana-R. padi & P. neoaphidis-R. padi & ne \\
E. planchoniana-R. padi & P. neoaphidis-S. avenae & ne \\
E. planchoniana-S. avenae & P. neoaphidis-R. padi & 0.050 \\
E. planchoniana-S. avenae & P. neoaphidis-S. avenae & 0.402 \\
P. neoaphidis-R. padi & P. neoaphidis-S. avenae & 0.941 \\
\hline
\end{tabular}

\section{Discussion}

In this study, we mimicked the situation occurring in a natural agro-ecosystem and found a significant difference in aphid susceptibilities, possibly related to aphid host and/or fungus species and eventually aphid behavior. The conspecific host $S$. avenae was significantly more susceptible to E. planchoniana infection than the heterospecific host $R$. padi. However, we did not find any significant differences between the susceptibility of R. padi and S. avenae to P. neoaphidis. Differences in 
susceptibility between aphid species and morphs towards entomophthoralean fungal infection have been shown in several studies [2,31-35].

Our method simulates a real-life situation, where aphids were allowed to settle on the leaves before fungal treatments. Thus, some of the differences can potentially be attributed to the tendency of R. padi to settle lower on the plant than S. avenae does. By this behavioral resistance [36], it achieves partial protection from the infective conidia that "shower" from above. The measured differences in susceptibility between R. padi and S. avenae to E. planchoniana may reflect a general higher resistance in $R$. padi to specific fungal treatments, making this aphid less susceptible to the infection. Even though we did not consider the aphid microbiome composition in this study, the variation in susceptibility could be linked to diversity of facultative endosymbionts in S. avenae and R. padi. It has been shown previously, that bacterial symbionts can provide protection to their hosts from natural enemies [37]. Facultative endosymbionts (i.e., Rigiella insecticola, Spiroplasma, Rickettsia) have been reported to provide a significant protection to Acyrthosiphon pisum against $P$. neoaphidis $[38,39]$ by reducing the mortality of their host and decreasing the fungal sporulation on the cadavers [38].

We did not find significant differences in the $\mathrm{LT}_{50}$ between either of the combinations of aphid or fungal species. The estimated $\mathrm{LT}_{50}$ values were within previously reported ranges for $P$. neoaphidis infection in both S. avenae and R. padi at $20^{\circ} \mathrm{C}$ [40] and $17^{\circ} \mathrm{C}$ [2], and for E. planchoniana infecting A. fabae [41]. Factors such as dose and incubation temperature can however influence the estimates [42]. In our bioassay, $66.0 \%$ of $R$. padi succumbed to P. neoaphidis infection, which was lower than reported previously [2].

In addition to counting the sporulating aphid cadavers, we also recorded the mortality of aphids with uncertain causes of deaths for each treatment. Interestingly, $26 \%$ of $R$. padi died with no visible fungal structures after treatment with E. planchoniana. Since we only used morphological tools to investigate infection, we cannot completely exclude fungal treatment as a cause of mortality. The relatively high mortality rate of $R$. padi could suggest a more specific host-pathogen relationship between this aphid and E. planchoniana. In fact, a previous study has reported a large genetic diversity among the fly-pathogenic Entomophthora compared to the relatively small aphid-pathogenic Entomophthora [43]. Such observations support the idea that host specialization might be an important factor in driving fungi within the genus Entomophthora and also the E. planchoniana virulence on aphids. The routine use of molecular techniques such as real-time qPCR [44] as additional means for detecting and quantifying the fungal pathogen in the dead aphids could further widen our knowledge on this highly structured interaction network.

The presence of P. neoaphidis or E. planchoniana infected aphid cadavers attached to a plant with healthy aphids could potentially enhance epizootic development [16]. Our results support this scenario, since both P. neoaphidis and E. planchoniana were able to infect both $S$. avenae and $R$. padi by conidia discharging from $S$. avenae cadavers. The coexistence of healthy and infected aphids occurring on the same host plant allows the transmission and establishment of fungal infections between conspecific and heterospecific aphids, in the latter case potentially with more resistance. Such observations might push forward attempts [45] to use entomophthoralean fungi as an effective biological control agent over insect pests.

\section{Conclusions}

We standardized a methodology to allow a direct comparison of entomophthoralean fungal virulence against two aphid hosts. The transmission model designed in this study shows a successful in vivo establishment of the infection by two specialized aphid pathogens, $P$. neoaphidis and E. planchoniana, in conspecific and heterospecific aphids; which should be implemented in future biological control programs against aphid pests in cereals. 
Supplementary Materials: The following are available online at http://www.mdpi.com/2075-4450/10/2/54/s1, Table S1: Aphid-mortality records over time (hours), after the two fungal treatments, for each aphid species. Replicates, number of incubated aphids, total numbers of dead aphids are presented. Total numbers of dead aphids, is split to deaths caused by fungus and those did not show any fungal infection symptom, and therefore, the cause of death could not be determined. Script S1: R code for analyzing the data including statistical tests and plotting.

Author Contributions: Conceptualization, I.B.F., A.B.J. and J.E.; data curation, I.B.F.; methodology, I.B.F.; project administration, A.B.J. and J.E.; software, G.P. and S.R.; supervision, A.B.J., S.B.-B. and J.E.; validation, A.B.J. and J.E.; writing—original draft, I.B.F.; writing—review and editing, I.B.F., A.B.J., S.B.-B., G.P., C.R. and J.E.

Funding: This article was part of the Ph.D. project of I.B.F., supported by the Ministry of Higher Education and Scientific Research of the Tunisian government through the grant Doctorate Program and the University of Copenhagen.

Conflicts of Interest: The authors declare no conflicts of interest.

\section{References}

1. $\quad$ Blackman, R.L.; Eastop, V.F. Taxonomic Issues. In Aphids as Crop Pests; Van Emden, H.F., Harrington, R., Eds.; CABI: Wallingford, UK, 2007; pp. 1-29. [CrossRef]

2. Nielsen, C.; Steenberg, T. Entomophthoralean fungi infecting the bird cherry-oat aphid, Rhopalosiphum padi, feeding on its winter host bird cherry, Prunus padus. J. Invertebr. Pathol. 2004, 78, 72-80. [CrossRef] [PubMed]

3. Dedryver, C.A.; Le Ralec, A.; Fabre, F. The conflicting relationships between aphids and men: A review of aphid damage and control strategies. C. R. Biol. 2010, 333, 539-553. [CrossRef] [PubMed]

4. Barta, M.; Cagan, L. Aphids-pathogenic Entomophthorales (their taxonomy, biology and ecology). Biologia 2006, 61, 543-616. [CrossRef]

5. Humber, R.A. Entomophthoromycota: A new phylum and reclassification for entomophthoroid fungi. Mycotaxon 2012, 120, 477-492. [CrossRef]

6. Ben Fekih, I.; Boukhris-Bouhachem, S.; Eilenberg, J.; Allagui, M.B.; Jensen, A.B. The Occurrence of two species of Entomophthorales (Entomophthoromycota), pathogens of Sitobion avenae and Myzus persicae (Hemiptera: Aphididae), in Tunisia. Biomed. Res. Int. 2013, 2013, 838145. [CrossRef] [PubMed]

7. Manfrino, R.G.; Gutierrez, A.C.; Steinkraus, D.C.; Salto, C.E.; Lopez Lastra, C.C. Prevalence of entomophthoralean fungi (Entomophthoromycota) of aphids (Hemiptera: Aphididae) on solanaceous crops in Argentina. J. Invertebr. Pathol. 2014, 121, 21-23. [CrossRef] [PubMed]

8. Lacey, L.A.; Frutos, R.; Kaya, H.K.; Vail, P. Insect pathogens as biological control agents: Do they have a future? Biol. Control 2001, 21, 230-248. [CrossRef]

9. Scorsetti, A.C.; Humber, R.A.; Garcia, J.J.; Lastra, C.C.L. Natural occurrence of entomopathogenic fungi (Zygomycetes: Entomophthorales) of aphid (Hemiptera: Aphididae) pests of horticultural crops in Argentina. Biocontrol 2007, 52, 641-655. [CrossRef]

10. Ben Fekih, I.; Boukhris-Bouhachem, S.; Allagui, M.B.; Jensen, A.B.; Eilenberg, J. First survey on ecological host range of aphid pathogenic fungi (Phylum Entomophthoromycota) in Tunisia. Ann. Soc. Entomol. Fr. (NS) 2015, 51, 140-144. [CrossRef]

11. Papierok, B.; Dedryver, C.A.; Hullé, M. First records of aphid-pathogenic Entomophthorales in the sub-Antarctic archipelagos of Crozet and Kerguelen. Polar Res. 2016, 35, 28765. [CrossRef]

12. Fournier, A. Assessing Winter Survival of the Aphid Pathogenic Fungus Pandora neoaphidis and Implications for Conservation Biological Control. Ph.D. Thesis, ETH, Zürich, Switzerland, 2010; pp. 1-131, No. 18945.

13. Lacey, L.A. Manual of Techniques in Invertebrate Pathology, 2nd ed.; Academic Press: San Diego, CA, USA, 2012; p. 504.

14. Eilenberg, J.; Bresciani, J.; Olesen, U.; Olson, L. Ultrastructural studies of secondary spore formation and discharge in the genus Entomophthora. J. Invertebr. Pathol. 1995, 65, 179-185. [CrossRef]

15. Roy, H.E.; Steinkraus, D.; Eilenberg, J.; Hajek, A.E.; Pell, J.K. Bizarre interactions and endgames: Entomopathogenic fungi and their arthropod hosts. Annu. Rev. Entomol. 2006, 51, 331-357. [CrossRef] [PubMed]

16. Steinkraus, D.C. Factors affecting transmission of fungal pathogens of aphids. J. Invertebr. Pathol. 2006, 92, 125-131. [CrossRef] [PubMed] 
17. Lacey, L.A.; Grzywacz, D.; Shapiro-Ilan, D.I.; Frutos, R.; Brownbridge, M.; Goettel, M.S. Insect pathogens as biological control agents: Back to the future. J. Invertebr. Pathol. 2015, 132, 1-41. [CrossRef] [PubMed]

18. Pell, J.K.; Eilenberg, J.; Hajek, A.E.; Steinkraus, D.C. Biology, ecology and pest management potential of Entomophthorales. In Fungi as Biocontrol Agents. Progress, Problems and Potential; Butt, T.M., Jackson, C.W., Magan, N., Eds.; CABII Publishing: Oxon, UK, 2001; pp. 71-153. ISBN 0-85199-356-7.

19. Hemmati, F.; Pell, J.K.; McCartney, H.A.; Deadman, M.L. Aerodynamic diameter of conidia of Erynia neoaphidis and other entomophthoralean fungi. Mycol. Res. 2002, 106, 233-238. [CrossRef]

20. Pell, J.K. Ecological approaches to pest management using entomopathogenic fungi: Concepts, theory, practice, and opportunities. In Use of Entomopathogenic Fungi in Pest Management; Ekesi, S., Manianai, N., Eds.; Research Signpost: Kerala, India, 2007; pp. 145-177.

21. Hajek, A.E.; Delalibera, I.J. Fungal pathogens as classical biological control agents against arthropods. BioControl 2010, 55, 147-158. [CrossRef]

22. Hajek, A.E.; Papierok, B.; Eilenberg, J. Methods for study of the Entomophthorales. In Manual of Techniques in Invertebrate Pathology, 2nd ed.; Lacey, L.A., Ed.; Academic Press: San Diego, CA, USA, 2012; pp. 285-315.

23. Shah, P.A.; Clark, S.J.; Pell, J.K. Direct and indirect estimates of Pandora neopahidis conidia in laboratory bioassays with aphids. J. Invertebr. Pathol. 2003, 84, 145-147. [CrossRef] [PubMed]

24. Humber, R.A. Fungi: Identification. In Manual of Techniques in Insect Pathology; Lacey, L.A., Ed.; Academic Press: San Diego, CA, USA, 1997; pp. 153-186.

25. Freeman, M.F.; Tukey, J.W. Transformations related to the angular and the square root. Ann. Math. Stat. 1950, 21, 607-611. [CrossRef]

26. R Core Team. R: A Language and Environment for Statistical Computing. 2012. Version 3.5. Available online: https: / /www.r-project.org/ (accessed on 20 November 2018).

27. Dowle, M.; Srinivasan, A. Data.Tableable: Extension of 'Data.Frame'. 2018. R Package Version 1.11.4. Available online: https: / CRAN.R-project.org/package=data.table (accessed on 20 November 2018).

28. Greenwell, B.M.; Kabban, C.M.S. Investr: An R Package for Inverse Estimation. Version 1.4.0. R J. 2014, 6 , 90-100. Available online: http:/ /journal.r-project.org/archive/2014-1/greenwell-kabban.pdf (accessed on 20 November 2018).

29. Scott Long, J.; Freese, J. Regression Models for Categorical Dependent Variables Using Stata; Stata Press: College Station, TX, USA, 2014.

30. Tukey, J. Comparing Individual Means in the Analysis of Variance. Biometrics 1949, 5, 99-114. [CrossRef] [PubMed]

31. Dromph, K.M.; Pell, J.K.; Eilenberg, J. Influence of flight and colour morph on susceptibility of Sitobion avenae to infection by Erynia neoaphidis. BioControl Sci. Technol. 2002, 12, 753-756. [CrossRef]

32. Shah, P.A.; Clark, S.J.; Pell, J.K. Assessment of aphid host range and isolate variability in Pandora neoaphidis (Zygomycetes: Entomophthorales). Biol. Control 2004, 29, 90-99. [CrossRef]

33. Xu, J.H.; Feng, M.G. The time-dose-mortality modeling and virulence indices for two entomophthoralean Species, Pandora delphacis and P. neoaphidis, against the green peach aphid, Myzus persicae. Biol. Control 2000, 17, 29-34. [CrossRef]

34. Ekesi, S.; Shah, P.A.; Clark, S.J.; Pell, J.K. Conservation biological control with the fungal pathogen Pandora neoaphidis: Implications of aphid species, host plant and predator foraging. Agric. Forest. Entomol. 2005, 7, 21-30. [CrossRef]

35. Hesketh, H.; Alderson, P.G.; Pye, B.J.; Pell, J.K. The development and multiple uses of a standardised bioassay method to select hypocrealean fungi for biological control of aphids. Biol. Control 2008, 46, 242-255. [CrossRef]

36. Jensen, S.E. Insecticide resistance in the western flower thrips, Frankliniella occidentalis. Integr. Pest Manag. Rev. 2000, 5, 131-146. [CrossRef]

37. Moran, N.A.; McCutcheon, J.P.; Nakabachi, A. Genomics and evolution of heritable bacterial symbionts. Annu. Rev. Genet. 2008, 42, 165-190. [CrossRef]

38. Łukasik, P.; Guo, H.; Van Asch, M.; Ferrari, J.; Godfray, H.C.J. Protection against a fungal pathogen conferred by the aphid facultative endosymbionts Rickettsia and Spiroplasma is expressed in multiple host genotypes and species and is not influenced by co-infection with another symbiont. J. Evol. Biol. 2013, 26, 2654-2661. [CrossRef] 
39. Heyworth, E.R.; Ferrari, J. A facultative endosymbiont in aphids can provide diverse ecological benefits. J. Evol. Biol. 2015, 28, 1753-1760. [CrossRef]

40. Nielsen, C.; Eilenberg, J.; Dromph, K. Entomophthorales on Cereal Aphids: Characterisation, Growth, Virulence, Epizootiology and Potential for Microbial Control; Ministry of Environment and Energy, Danish Environmental Protection Agency: Copenhagen, Denmark, 2001; p. 75.

41. Brobyn, P.; Wilding, N. Invasive and developmental processes of Entomophthora species infecting aphids. Trans. Br. Mycol. Soc. 1977, 69, 349-366. [CrossRef]

42. Feng, M.G.; Poprawski, T.J.; Nowierski, R.M.; Zeng, Z. Infectivity of Pandora neoaphidis (Zygomycetes: Entomophthorales) to Acyrthosiphon pisum (Hom., Aphididae) in response to varying temperature and photoperiod regimes. J. Appl. Entomol. 1999, 123, 29-35. [CrossRef]

43. Jensen, A.B.; Eilenberg, J.; Lastra, C.L. Differentially aphid and fly host driven divergence of obligate insect pathogenic Entomophthora species. FEMS Microbiol. Lett. 2009, 300, 180-187. [CrossRef] [PubMed]

44. Chen, C.; Ye, S.; Hu, H.; Xue, C.; Yu, X. Use of electrical penetration graphs (EPG) and quantitative PCR to evaluate the relationship between feeding behaviour and Pandora neoaphidis infection levels in green peach aphid, Myzus persicae. J. Insect Physiol. 2018, 104, 9-14. [CrossRef] [PubMed]

45. Dinu, M.M.; Bloemhard, C.M.J.; van Holstein-Saj, R.; Messelink, G.J. Exploring opportunities to induce epizootics in greenhouse aphid populations. Acta Hortic. 2017, 1164, 371-376. [CrossRef]

(C) 2019 by the authors. Licensee MDPI, Basel, Switzerland. This article is an open access article distributed under the terms and conditions of the Creative Commons Attribution (CC BY) license (http://creativecommons.org/licenses/by/4.0/). 